\title{
Metabolism of urea
}

\section{in late pregnancy and the possible contribution of amino acid carbon to glucose synthesis in sheep}

\author{
By J. V. NOLAN AND R. A. LENG \\ Department of Biochemistry and Nutrition, School of Rural Science, \\ University of New England, Armidale, NSW 2351, Australia
}

(Received 3 November 1969-Accepted 6 April 1970)

\begin{abstract}
I. Metabolism of urea in non-pregnant and pregnant sheep ( $\mathrm{I}-25 \mathrm{~d}$ from term) has been examined. Injections of $\left[{ }^{14} \mathrm{C}\right]$ urea were used to estimate urea entry rate, urea pool size and urea space in sheep given $1000 \mathrm{~g}$ of a diet of equal parts of crushed oats and chaffed lucerne hay (day $a$ ) and in the same sheep $4 \mathrm{~d}$ after the ration had been reduced to $250 \mathrm{~g}$ (day $b$ ).

2. On both experimental days $(a$ and $b$ ), mean pool size was greater ( $14 \%$ on day $a, 29 \%$ on day $b)$ and urea space was greater $(54 \%$ on day $a, 24 \%$ on day $b)$ in pregnant animals than in non-pregnant animals; mean plasma urea concentrations were lower $(35 \%)$ in the pregnant animals on day $a$ but were not significantly different on day $b$.

3. The entry rate of urea was similar in all the animals on day $a$, but was significantly higher $(34 \%)$ in pregnant than in non-pregnant animals on day $b$. There was a significant decrease in urea entry rate in both pregnant $(33 \%)$ and non-pregnant $(86 \%)$ animals on day $b$.

4. The rate of excretion of urea was lower $(26 \%$ on day $a, 35 \%$ on day $b)$ in pregnant animals, indicating a higher ( $31 \%$ on day $a, 40 \%$ on day $b$ ) rate of degradation of urea in the digestive tract of pregnant as compared with non-pregnant sheep.

5. Measurements of urea entry rate have been used to calculate the upper limit of amino acid deamination in pregnant and non-pregnant sheep, and this has been used as an indication of the potential availability of amino acid carbon for glucose synthesis. It is suggested that, at a maximum, amino acids may have contributed the carbon required for $63 \mathrm{~g} / \mathrm{d}$ and $52 \mathrm{~g} / \mathrm{d}$ of glucose on days $a$ and $b$ respectively.
\end{abstract}

Degradation of urea occurs in all animals and depends on urease of bacterial origin in the digestive tract (Dintzis \& Hastings, I953; Kornberg, Davies \& Wood, I954; Levenson, Crowley, Horowitz \& Malm, I959; Rahman \& Decker, I966). Ruminants, in particular, appear to hydrolyse a considerable amount of endogenously produced urea, and the ammonia produced is available for microbial cell synthesis in the places where bacterial growth occurs (i.e. the rumen together with the caecum and large intestine) (see review by Phillipson, 1964). Such a mechanism for retention of nitrogen enables the sheep to exist on diets which are lower in protein than those required by monogastric animals. Ewes in late pregnancy appear to have a greater requirement for protein than non-pregnant animals and the transfer of urea to the digestive tract may allow these animals to meet their protein requirements which increase as pregnancy progresses (Robinson \& Forbes, 1967).

The main substrate for energy of the foetus is believed to be glucose (Barcroft, I946; Reid, I960) and ewes given a constant ration synthesize more glucose as pregnancy progresses (Steel \& Leng, I968). Only relatively small quantities of glucose are absorbed from the alimentary tract of sheep given roughage diets (see review by Armstrong \& Beever, 1969) so the glucose required must be provided by gluconeo- 
genesis. At least half the glucose synthesized in non-pregnant sheep on roughage diets appears to arise from propionate (Leng, Steel \& Luick, I967; Judson \& Leng, I968) and the quantity of propionate produced in the rumen which is used for glucose synthesis remains constant as pregnancy progresses (Steel \& Leng, 1968). A considerable proportion of the glucose entering the body pool of glucose therefore arises from substrates other than propionate, and the proportion increases as pregnancy progresses. Glycerol provides approximately $28 \%$ of the glucose synthesized in starved $(4 \mathrm{~d})$ pregnant sheep ( $1-3$ weeks from term) (Bergman, Starr \& Reulein, 1968) but no estimates are available for pregnant sheep that are fed. Amino acids are a source of glucose in both ruminant and non-ruminant animals and it has been suggested, from measurements of urinary nitrogen excretion, that amino acids are the major substrates for gluconeogenesis in pregnant sheep (Kronfeld, 1957; Bergman, Roe \& Kon, I 966). However, the use of total nitrogen or urea excretion in urine as an index of protein deamination may be misleading because, under some circumstances, urea synthesized as a result of deamination of amino acids may not be excreted in the urine. For instance, in sheep that are starved, urea storage in the body pool of urea increases (Packett \& Groves, 1965; Cocimano \& Leng, 1967) and on low-protein diets some of the urea synthesized may be recycled to the digestive tract and utilized for microbial growth (Schmidt-Nielsen, Schmidt-Nielsen, Houpt \& Jarnum, I957; Clark, I965; Cocimano \& Leng, 1967).

In the present studies, the rate of entry of urea into the body pool of urea was used to indicate the upper limit of net amino acid deamination, and from this the potential rate of glucose synthesis from deaminated carbon residues was derived. These investigations were made in conjunction with a study of the energy and nitrogen metabolism of undernourished pregnant sheep (Graham, I968) and were also part of a continuing study of nitrogen and urea metabolism in sheep; measurements made previously (Cocimano \& Leng, 1967) can now be compared with those for pregnant and non-pregnant sheep of a different breed and heavier body-weight. It is hoped that eventually it may be possible to predict, by reference to nutritional or biochemical measurements, whether urea added to the diet of sheep and cattle will increase utilization of low-protein feeds. A preliminary report of part of this work has appeared elsewhere (Nolan \& Leng, r 968 ).

\section{EXPERIMENTAL}

Animals and feeding regimen. Corriedale ewes (age 3-6 years) mated by a Dorset Horn ram were examined for the presence of foetuses by X-rays about $80 \mathrm{~d}$ after mating and sheep with single or twin foetuses were selected. Non-pregnant sheep that had not been mated were obtained from the same flock. They were held indoors in individual pens and given a ration of $1000 \mathrm{~g}$ of equal parts of crushed oats and chaffed lucerne hay (period A) until ro-25 $\mathrm{d}$ before term when the ration was abruptly reduced to $250 \mathrm{~g}$ (period B). During period A, the ration appeared to provide adequate quantities of nutrients for rapid growth of the foetuses. The measurements detailed below were made on two different days, the first was during period $A$, and was $I-2 d$ before the 


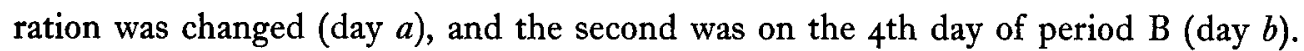
For $7 \mathrm{~d}$ before the first measurements the animals were given their daily ration in equal portions at $3 \mathrm{~h}$ intervals in order to produce a relatively steady state in the sheep. The concentration of urea in the blood did not fluctuate markedly throughout the day.

Experimental procedures. The sheep were prepared with jugular vein catheters on the day before an experiment. $\left[{ }^{14} \mathrm{C}\right]$ urea $(6 \mathrm{mg} ; 70 \mu \mathrm{Ci})$ was injected into each animal at o6.0o hours and blood samples were taken at 2 and $4 \mathrm{~h}$ after the injection and then at $30 \mathrm{~min}$ intervals from 6 to $\mathrm{Io} \mathrm{h}$ after the injection. These blood samples were centrifuged and plasma samples were stored at $-20^{\circ}$. A blood sample taken at 15.30 hours (midway between two feeding periods) was retained for measurement of concentrations of plasma glucose and plasma ketone bodies.

Chemical methods. Glucose was determined by the glucose oxidase method of Huggett \& Nixon (1957) and ketone bodies by the method of Tanayama \& Ui (1963). The specific radioactivity of plasma urea was measured after deproteinization of plasma $(2 \mathrm{ml})$ by the successive additions of $4 \mathrm{ml}$ water, $2 \mathrm{ml} 0.5 \mathrm{~N}-\mathrm{Ba}(\mathrm{OH})_{2}$ and $2 \mathrm{ml}$ $7 \%(\mathrm{w} / \mathrm{v}) \mathrm{ZnSO}_{4}$. The supernatant liquid ( $\mathrm{I} \mathrm{ml}$ ) was counted in $10 \mathrm{ml}$ of Triton X-Ioo scintillation mixture (Patterson \& Greene, 1965$)$ in a Nuclear Chicago Scintillation Spectrometer (Nuclear Chicago, Des Plaines, Illinois). The urea concentration of the same supernatant liquid was measured using an AutoAnalyzer (Technicon, New York) and the diacetyl monoxime method of Marsh, Fingerhut \& Kirsch (1957).

The rate at which urea entered the body pool of urea (urea entry rate), urea pool size and urea space were calculated from the decline of specific radioactivity of urea in blood as described by Cocimano \& Leng (1967).

The rate of excretion of urea was estimated from the concentration of urea in urine samples collected quantitatively (Raabe, ${ }^{2} 968$ ) into $5 \mathrm{ml}$ of conc. $\mathrm{H}_{2} \mathrm{SO}_{4}$ on days $a$ and $b$ and stored at $3^{\circ}$. Concentration of urea in urine was measured by an automated urease method (Wilson, 1966).

\section{RESULTS}

Details of energy metabolism and nitrogen excretion in the animals used in these investigations have been given by Graham ( 1968 ). However, the concentration of some constituents of blood are reproduced in Table i for comparison with the other results presented here and as an indication of the relative nutritional status of the pregnant and non-pregnant animals.

Urea metabolism. Fig. I shows the relationships of log specific radioactivity of blood urea with time after single injections of $\left[{ }^{14} \mathrm{C}\right]$ urea given intravenously into nonpregnant sheep or sheep with one or two foetuses, before (day $a$ ) and $4 \mathrm{~d}$ after a $75 \%$ reduction in food intake (day $b$ ). Considerable variations in urea entry rates were observed between the pregnant and non-pregnant animals and between day $a$ and day $b$ (Fig. 2 and Table I).

Fig. 2 shows the rates of entry, excretion and degradation of urea; Fig. 3 shows plasma urea concentration, urea pool size and space of distribution; Fig. 4 shows urine flow rate, the ratio of urine urea to plasma urea concentrations (i.e. urea $U: P$ ratio) and rate of clearance of urea (plasma urea concentration/urine flow). All the values are 
results for non-pregnant and pregnant sheep during the last $25 \mathrm{~d}$ of pregnancy on a high plane of nutrition ( $\operatorname{day} a$ ) and for the same animals after $4 \mathrm{~d}$ of undernutrition (day $b$ ).

Table I. Statistical comparisons of the metabolism of urea in pregnant $(P)$ and nonpregnant (NP) sheep given $1000 \mathrm{~g} / \mathrm{d}$ of a ration of equal parts of crushed oats and chaffed lucerne (day a) and in the same sheep $4 d$ after the ration was changed to $250 \mathrm{~g} / \mathrm{d}$ of the same diet $($ day $\mathrm{b})$. The group of pregnant animals contained two ewes with twin foetuses and seven ewes with single foetuses. Each pair of means has been examined independently

\begin{tabular}{|c|c|c|c|c|c|c|}
\hline \multirow{3}{*}{ Urea entry rate $(\mathrm{g} / \mathrm{d})$} & \multicolumn{3}{|c|}{ Day $a$} & \multicolumn{2}{|c|}{ Day $b$} & \multirow{3}{*}{$\begin{array}{c}\text { Level of } \\
\text { significance } \\
\text { between } \\
\text { days† } \\
\text { *** } \\
* * *\end{array}$} \\
\hline & \multicolumn{2}{|c|}{ Mean } & \multirow{2}{*}{$\left.\begin{array}{c}\text { SE } \\
\mathbf{2} \cdot \mathbf{2} \\
I \cdot I\end{array}\right\} N S$} & \multirow{2}{*}{$\begin{array}{l}\text { Mean } \\
22 \\
30\end{array}$} & \multirow{2}{*}{$\left.\begin{array}{c}\text { SE } \\
0 \cdot 8 \\
1 \cdot 3\end{array}\right\} * * *$} & \\
\hline & $\begin{array}{r}\mathrm{NP} \\
\mathrm{P}\end{array}$ & $\begin{array}{l}4 I \\
40\end{array}$ & & & & \\
\hline $\begin{array}{l}\text { Urea excretion rate } \\
(\mathrm{g} / \mathrm{d})\end{array}$ & $\begin{array}{r}\mathrm{NP} \\
\mathrm{P}\end{array}$ & $\begin{array}{l}28 \\
23\end{array}$ & $\left.\begin{array}{l}\mathbf{I} \cdot 9 \\
\mathbf{I} \cdot 3\end{array}\right\} * * *$ & $\begin{array}{l}17 \\
22\end{array}$ & $\left.\begin{array}{c}0.9 \\
I \cdot 2\end{array}\right\} * * *$ & NS \\
\hline $\begin{array}{l}\text { Urea degradation rate } \\
(\mathrm{g} / \mathrm{d})\end{array}$ & $\begin{array}{r}\mathrm{NP} \\
\mathrm{P}\end{array}$ & $\begin{array}{l}13 \\
17\end{array}$ & $\left.\begin{array}{l}\mathbf{I} \cdot 0 \\
I \cdot 0\end{array}\right\} * * *$ & $\begin{array}{l}5 \\
7\end{array}$ & $\left.\begin{array}{l}0.7 \\
0.8\end{array}\right\} * * *$ & **** \\
\hline $\begin{array}{l}\text { Plasma urea con- } \\
\text { centration }(\mathrm{mg} / 100 \mathrm{ml})\end{array}$ & $\begin{array}{r}\mathrm{NP} \\
\mathrm{P}\end{array}$ & $\begin{array}{l}46 \\
34\end{array}$ & $\left.\begin{array}{l}3.0 \\
2.6\end{array}\right\} * * *$ & $\begin{array}{l}34 \\
36\end{array}$ & $\left.\begin{array}{l}3 \cdot 1 \\
1 \cdot 7\end{array}\right\} N S$ & NS \\
\hline Pool size (g) & $\begin{array}{r}\text { NP } \\
P\end{array}$ & $\begin{array}{l}\text { II } \\
\text { I2 }\end{array}$ & $\left.\begin{array}{l}\begin{array}{l}1 \cdot 0 \\
0.9\end{array}\end{array}\right\} *$ & $\begin{array}{r}9 \\
\mathbf{I} I\end{array}$ & $\left.\begin{array}{l}0.6 \\
0.6\end{array}\right\} * * *$ & $\begin{array}{l}\text { NS } \\
\text { NS }\end{array}$ \\
\hline Urea space (I) & $\begin{array}{r}\mathrm{NP} \\
\mathrm{P}\end{array}$ & $\begin{array}{l}24 \\
37\end{array}$ & $\left.\begin{array}{l}2 \cdot 2 \\
2 \cdot 0\end{array}\right\} * * *$ & $\begin{array}{l}26 \\
33\end{array}$ & $\left.\begin{array}{l}I \cdot I \\
I \cdot 9\end{array}\right\} * * *$ & $\begin{array}{l}\mathrm{NS} \\
* * *\end{array}$ \\
\hline $\begin{array}{l}\text { Urine flow rate } \\
(\mathrm{ml} / \mathrm{d})\end{array}$ & $\begin{array}{r}\mathrm{NP} \\
\mathrm{P}\end{array}$ & $\begin{array}{l}\text { I7I } \\
926\end{array}$ & $\left.\begin{array}{l}236 \\
366\end{array}\right\} * * *$ & $\begin{array}{l}1258 \\
3380\end{array}$ & $\left.\begin{array}{l}424 \\
767\end{array}\right\} * * *$ & $\begin{array}{l}\text { NS } \\
\text { NS }\end{array}$ \\
\hline Ratio, urea U:Pł & $\begin{array}{r}\text { NP } \\
\mathbf{P}\end{array}$ & $\begin{array}{l}63 \\
50\end{array}$ & $\left.\begin{array}{l}10 \cdot 2 \\
11.0\end{array}\right\} *$ & $\begin{array}{l}68 \\
27\end{array}$ & $\left.\begin{array}{r}16 \cdot 6 \\
6 \cdot 1\end{array}\right\} * * *$ & $\begin{array}{l}\text { NS } \\
\text { NS }\end{array}$ \\
\hline $\begin{array}{l}\text { Urea clearance } \\
(\mathrm{ml} / \mathrm{min})\end{array}$ & $\begin{array}{r}\mathrm{NP} \\
\mathrm{P}\end{array}$ & $\begin{array}{l}44 \\
47\end{array}$ & $\left.\begin{array}{l}3 \cdot 9 \\
2 \cdot 3\end{array}\right\} *$ & $\begin{array}{l}33 \\
45\end{array}$ & $\left.\begin{array}{l}3 \cdot 4 \\
3 \cdot 4\end{array}\right\} * * *$ & $\begin{array}{l}\text { NS } \\
\text { NS }\end{array}$ \\
\hline $\begin{array}{l}\text { Plasma glucose } \\
\text { concentration } \\
(\mathrm{mg} / 100 \mathrm{ml})\end{array}$ & $\begin{array}{r}\mathrm{NP} \\
\mathrm{P}\end{array}$ & $\begin{array}{l}77 \\
68\end{array}$ & $\left.\begin{array}{l}2 \cdot 8 \\
3 \cdot 0\end{array}\right\} * * *$ & $\begin{array}{l}69 \\
35\end{array}$ & $\left.\begin{array}{l}4.0 \\
1 \cdot 6\end{array}\right\} * * *$ & * $* *$ \\
\hline $\begin{array}{l}\text { Plasma ketone body } \\
\text { concentration } \\
\text { (mg acetone/10o ml) }\end{array}$ & $\begin{array}{r}\mathrm{NP} \\
\mathrm{P}\end{array}$ & $\begin{array}{r}7 \\
\text { I0 }\end{array}$ & $\overline{-} \cdot 5\} \mathrm{NS}$ & $\begin{array}{r}7 \\
45\end{array}$ & I0.0 $\} * * *$ & $\underset{* * *}{\mathrm{NS}}$ \\
\hline Body-weight $(\mathrm{kg})$ & $\begin{array}{r}\mathrm{NP} \\
\mathrm{P}\end{array}$ & $\begin{array}{l}58 \\
50\end{array}$ & $\left.\begin{array}{l}2 \cdot 4 \\
2 \cdot 4\end{array}\right\} * * *$ & $\begin{array}{l}48 \\
54\end{array}$ & $\left.\begin{array}{l}2 \cdot 2 \\
2 \cdot 2\end{array}\right\} * * *$ & *** \\
\hline
\end{tabular}

NS, not significant $(P>0.05)$; $P<0.05$; * $P<0.01$; *** $P<0.00 \mathrm{r}$

$\dagger$ Significance level for $t$ test of the paired differences between each sheep on day $a$ and day $b$.

$\ddagger$ Ratio of urinary urea concentration to plasma urea concentration.

The mean results for each group are given in Table $\mathbf{I}$ with the levels of significance between groups of animals and between feeding periods (i.e. days $a$ and $b$ ).

Potential for glucose synthesis from amino acids. The maximum possible glucose synthesis from amino acids was calculated (Table 2) by assuming that if all the glucogenic amino acid residues from $100 \mathrm{~g}$ protein could be converted into glucose, the carbonaceous residues could potentially yield $55 \mathrm{~g}$ of glucose (Krebs, 1964). The net rate of deamination of animo acids was obtained by assuming that $35 \mathrm{~g}$ of urea were 
synthesized from the ammonia produced from $100 \mathrm{~g}$ protein metabolized, i.e. $35 \mathrm{~g}$ of urea enters the body pool of urea from $100 \mathrm{~g}$ of protein metabolized and $55 \mathrm{~g}$ glucose may become available from the protein residues.

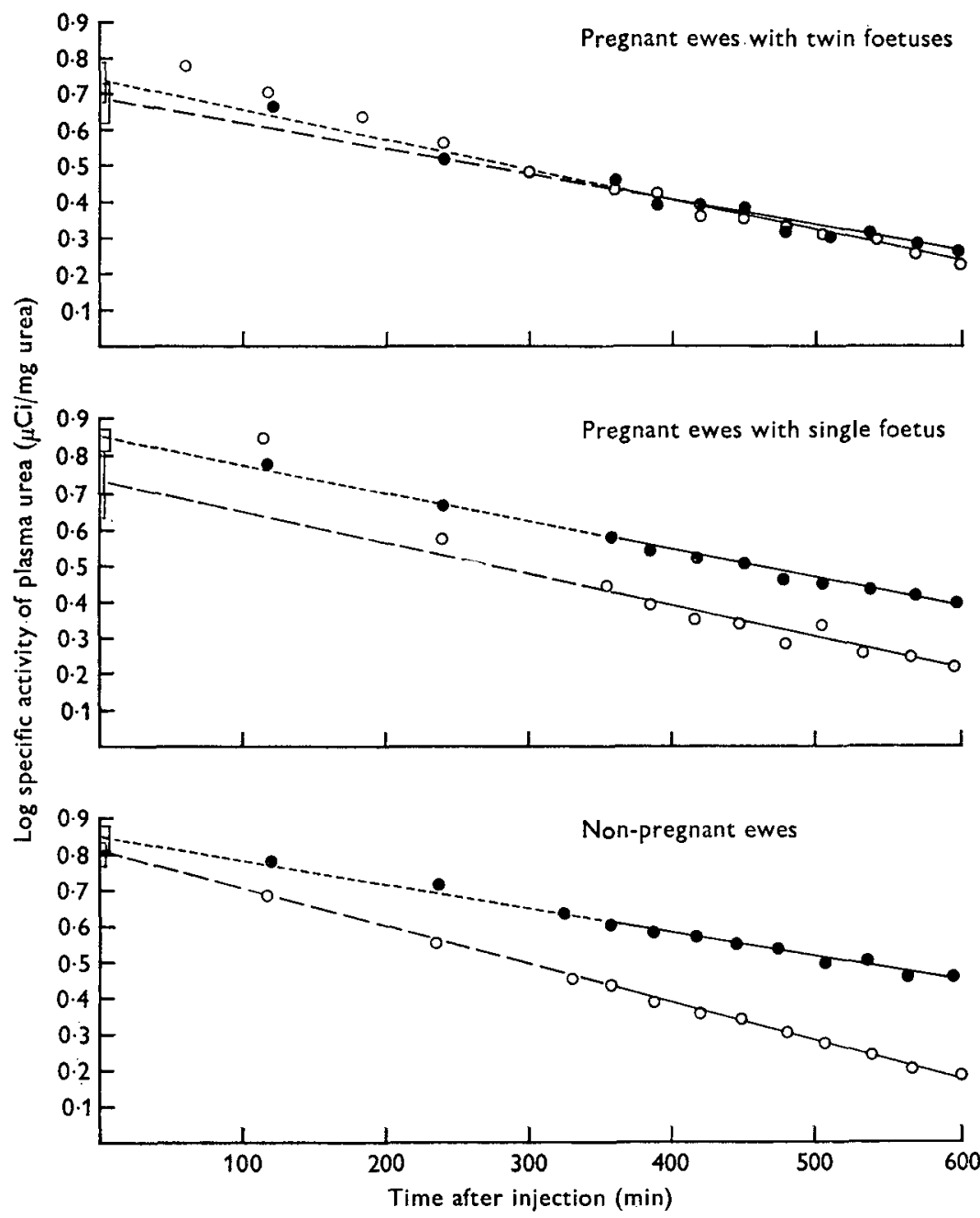

Fig. 1. Log specific radioactivity of plasma urea following a single injection of $\left[{ }^{14} \mathrm{C}\right]$ urea $(6 \mathrm{mg} ; 70 \mu \mathrm{Ci})$ into the jugular vein of non-pregnant and of pregnant sheep with twin or single foetuses on day $a(0)$ and on day $b(0)$. Rations on day $a$ and day $b$ are given in the heading to Table I. The $95 \%$ confidence interval for the specific radioactivity at time zero obtained by extrapolation of specific radioactivity values between 360 and 600 min after injection is shown (]).

\section{DISCUSSION}

In the studies of Cocimano \& Leng (1967), the sheep used were Merinos with bodyweights ranging between 25 and $40 \mathrm{~kg}$. Corriedale ewes with body-weights between $4^{2}$ and $69 \mathrm{~kg}$ were used in the present studies and, where the results of these studies can be compared, relationships obtained are similar to those reported earlier (Coci- 
mano \& Leng, I 967 ) if body-weight is taken into consideration. Only a proportion of the urea that entered the body pool of urea was excreted, indicating again that a considerable proportion of the urea produced entered the digestive tract and was degraded in both pregnant and non-pregnant ewes (see Fig. 2).

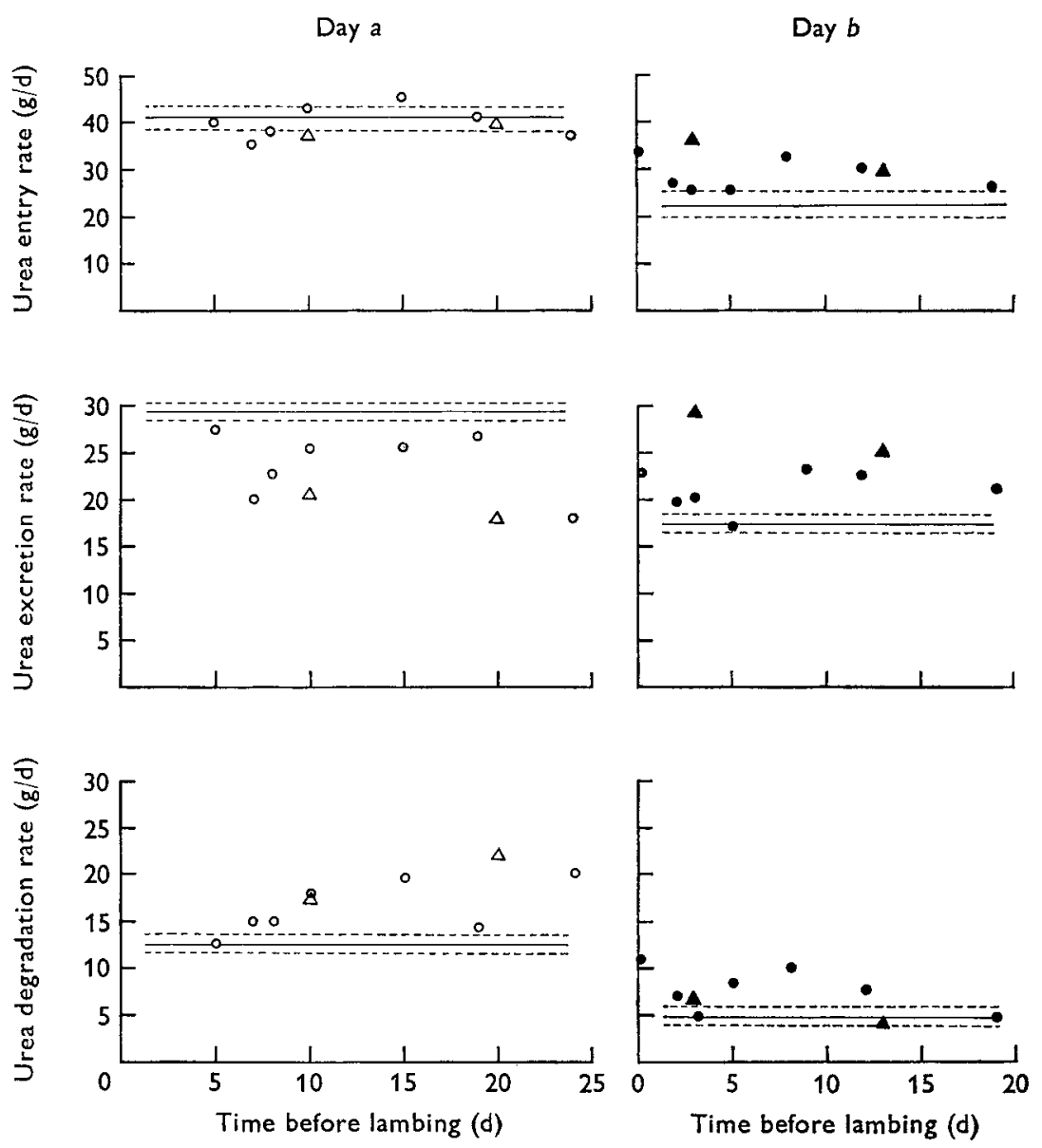

Fig. 2. Comparison of entry rate, excretion rate and degradation rate (entry rate minus excretion rate) of urea in non-pregnant ewes and in pregnant ewes at different times in late pregnancy. Rations on day $a$ and day $b$ are given in the heading to Table 1 . Means for the non-pregnant ewes are included for comparison and are given by the unbroken line, with the standard error as broken lines. (O) pregnant sheep with single foetuses on day $a$; (O) same sheep on day $b ;(\triangle)$ pregnant sheep with twin foetuses on day $a ;(\Delta)$ same sheep on day $b$.

There are reports of a decreased capacity for urea formation in some animal species during pregnancy (Botella-Llusia, 1936; Beaton, 1957), but there was no evidence for this in these studies with sheep. The entry rates of urea measured on day a were not significantly different between pregnant and non-pregnant sheep, and on day $b$ the pregnant animals had rates of entry of urea which were considerably higher than those for non-pregnant animals. The higher rates of entry of urea measured during the underfeeding period in pregnant animals compared with those for non-pregnant 
animals may have been due to a greater deamination of amino acids of exogenous and endogenous origin.

The rate of urea excretion on day $a$ was less in the pregnant group, despite a greater urine flow rate, than in the non-pregnant group. There was no evidence in these
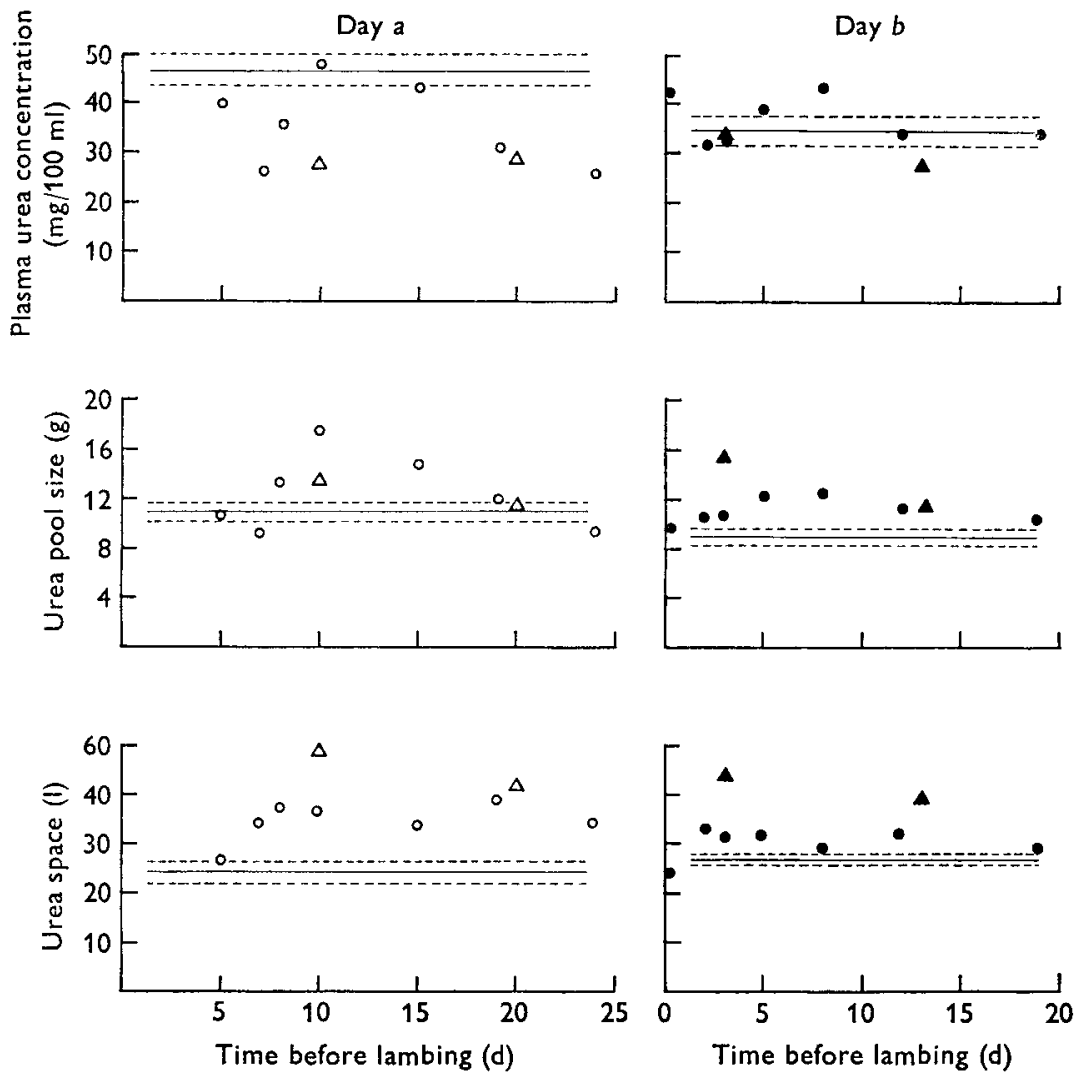

Fig. 3. Plasma urea concentration, pool size and space of distribution of urea in pregnant and non-pregnant sheep. Rations on day $a$ and day $b$ are given in the heading to Table $\mathrm{I}$, and the explanation of the symbols is given in the legend to Fig. 2.

studies for any control of urea excretion at the kidney tubular level (Graham, 1968) and it seems more likely that the lower rate of urinary urea excretion in the pregnant group on day $a$ was related to the lower plasma urea concentration (Cocimano \& Leng, 1967 ) or to factors affecting the rate of return of urea to the digestive tract.

The rate of degradation of urea was considerably higher in the pregnant animals than in the non-pregnant animals on both experimental days and this appeared not to be related to the concentration of urea in the plasma, which was lower in the pregnant than in the non-pregnant animals on day $a$ and not different on day $b$. The difference in the rate of degradation of urea between the pregnant and non-pregnant animals decreased significantly on day $a$ as the time of lambing approached, but tended to increase on day $b$. These changes in rate of degradation of urea may also suggest that there was some control of urea entering the digestive tract. If the rate of salivary 
flow were increased in pregnancy, this might account for some increased degradation rate of urea, but it has been suggested that the quantity of urea entering the rumen in saliva may be only small in relation to that diffusing across the rumen wall (Houpt, 1959; Waldo, 1968). The quantity of urea entering the rumen by passage across the

Day a
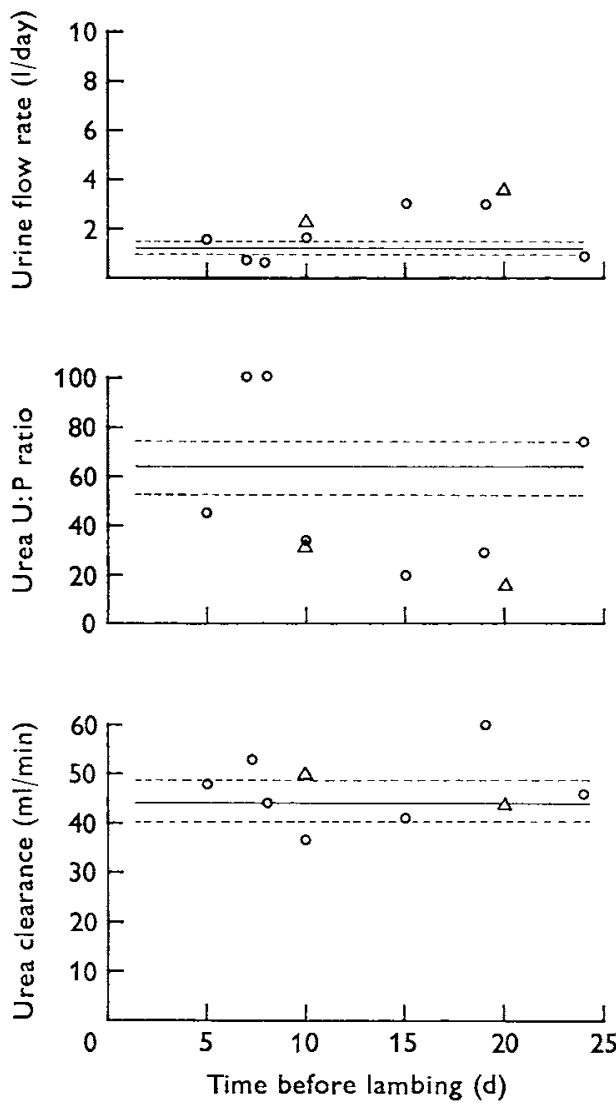

Day $b$
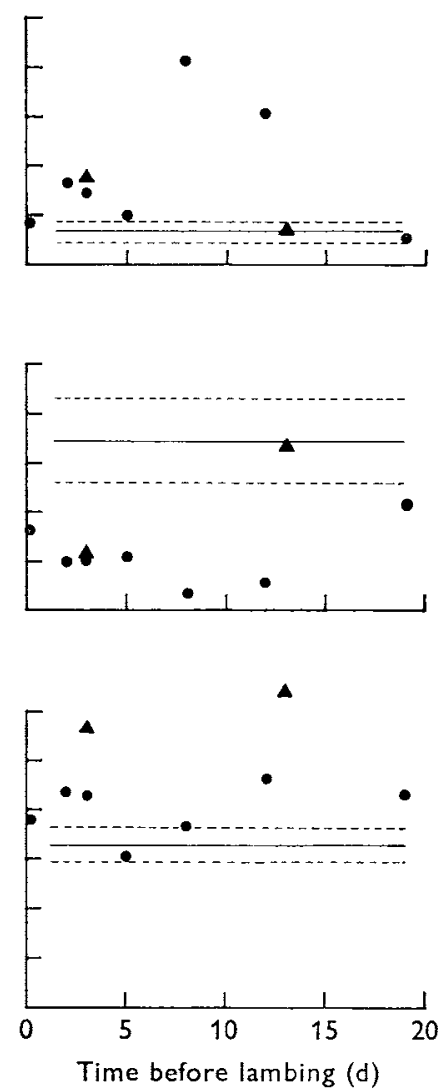

Fig. 4. Urine flow rate, ratio of urinary urea concentration to plasma urea concentration (urea $\mathrm{U}: \mathrm{P}$ ratio) and urea clearance in pregnant and non-pregnant sheep. Rations on day $a$ and day $b$ are given in Table $I$, and the explanation of the symbols is given in the legend to Fig. 2.

rumen wall could be affected by the concentration or distribution of bacterial urease in the rumen epithelium (Rahman \& Dekker, r966) or by changes in the flow of water across the rumen wall (von Engelhardt $\&$ Nickel, 1965), or by changes in the rate of blood flow to the rumen with the increased cardiac output of pregnancy (Assali, Dilts, Plentl, Kirschbaum \& Gross, 1968) which may facilitate an increased clearance of urea from blood by the rumen. Because of the presence of bacterial urease, degradation of urea occurs also in the lower digestive tract. It appears that the concentration of urea in the fluid in the small intestine probably attains the concentration of urea in plasma; some of this urea passes along the digestive tract and is degraded to ammonia in the areas of bacterial colonization (Hecker, 1967 ). If this is so, an increase in the rate of 
flow of digesta during pregnancy (Graham \& Williams, 1962; Forbes, 1968) or a greater net secretion of fluids into the abomasum or the first part of the intestine, which do not contain active bacterial urease, would result in a greater rate of degradation of urea.

The pregnant sheep appeared to be able to retain more urea in the body than the non-pregnant sheep, and this was distributed in a larger volume of body water (Table I). Urea is distributed through the foetus and foetal membranes (Alexander, Nixon, Widdas \& Wohlzogen, r 958) which is consistent with the apparent slower rate of equilibration of $\left[{ }^{14} \mathrm{C}\right]$ urea in pregnant animals than in non-pregnant animals (Fig. I).

Table 2. Possible synthesis of glucose from amino acid carbon in pregnant and nonpregnant sheep calculated from the rate of entry of urea before and after being subjected to undernutrition in late pregnancy. Mean concentrations of glucose and ketone bodies in plasma and total foetal weights of lambs are also given as an indication of the nutritional status of the ewes

\begin{tabular}{|c|c|c|c|c|c|c|c|c|c|c|c|c|c|c|}
\hline \multirow{3}{*}{$\begin{array}{l}\text { No. of } \\
\text { ewes } \\
\text { in } \\
\text { each } \\
\text { group }\end{array}$} & \multirow{3}{*}{$\begin{array}{l}\text { No. of } \\
\text { foetuses } \\
\text { per } \\
\text { ewe }\end{array}$} & \multirow{3}{*}{$\begin{array}{l}\text { Total } \\
\text { foetal } \\
\text { weight } \\
\text { per } \\
\text { ewe } \\
(\mathrm{kg})^{*}\end{array}$} & \multicolumn{4}{|c|}{$\begin{array}{l}\text { Urea entry rate } \\
(\mathrm{g} / \mathrm{d})\end{array}$} & \multirow{2}{*}{\multicolumn{2}{|c|}{$\begin{array}{c}\text { Possible } \\
\text { glucose } \\
\text { synthesis } \\
\text { from } \\
\text { amino acid } \\
(\mathrm{g} / \mathrm{d})\end{array}$}} & \multicolumn{4}{|c|}{$\begin{array}{l}\text { Plasma glucose } \\
\text { concentration } \\
(\mathrm{mg} / 100 \mathrm{ml})\end{array}$} & \multirow{2}{*}{\multicolumn{2}{|c|}{$\begin{array}{c}\begin{array}{c}\text { Plasma } \\
\text { ketone } \\
\text { concentration } \\
\text { (mg acetone } / \\
\text { I00 ml) } \dagger\end{array}\end{array}$}} \\
\hline & & & \multicolumn{2}{|c|}{ Day $a$} & \multicolumn{2}{|c|}{ Day $b$} & & & \multicolumn{2}{|c|}{ Day $a$} & \multicolumn{2}{|c|}{ Day $b$} & & \\
\hline & & & Mean & $\mathrm{SE}$ & Mean & SE & Mean & Mean & Mean & $\mathrm{SE}$ & Mean & SE & Mean & Mean \\
\hline 6 & o & - & $4 I$ & $1 \cdot 7$ & 22 & $\mathrm{I} \cdot 9$ & 64 & 35 & 77 & $6 \cdot 2$ & 67 & $9 \cdot 8$ & 7 & 7 \\
\hline 7 & $\mathbf{I}$ & $4^{\cdot 6}$ & 40 & $I \cdot I$ & 29 & $\mathbf{I} \cdot \mathbf{I}$ & 63 & 45 & 72 & $6 \cdot 5$ & 36 & $4 \cdot 3$ & I I & 36 \\
\hline 2 & 2 & $6 \cdot 6$ & 39 & $1 \cdot 7$ & 33 & $4 \cdot 5$ & $6 I$ & 52 & $5^{6}$ & $I \cdot 4$ & 30 & $2 \cdot 0$ & 10 & 53 \\
\hline
\end{tabular}

The pregnant sheep return a larger proportion of the urea synthesized to the digestive tract and are thus potentially able to digest more than non-pregnant sheep of a diet which is low in protein but high in cellulose.

A major objective of this work was to examine the potential deamination rate of amino acids and therefore the potential rate of glucose synthesis from protein in well-fed and underfed pregnant and non-pregnant sheep. If the net rate of deamination of amino acids is predicted from the urea or total nitrogen excreted in the urine (Kronfeld, I957; Graham, 1968; Bergman et al. 1966), underestimation may occur if (a) there is a retention of urea in the body pool (Packett \& Groves, 1965 ; Cocimano \& Leng, 1967 ) or $(b)$ there is considerable utilization of endogenous urea in the digestive tract through the internal cycle, bacterial protein $\rightarrow$ amino acids in small intestine $\rightarrow$ blood amino acids $\rightarrow$ deamination in the liver $\rightarrow$ urea $\rightarrow$ rumen $\mathrm{NH}_{4}^{+} \rightarrow$ bacterial protein. Conversely, if ammonia from degradation of plant proteins is absorbed, this may cause overestimation of the net deamination rate.

Whereas estimates of the quantity of amino acids deaminated based on the rate of nitrogen or urea excretion in the urine may be high or low, estimates based on the rate of entry of urea must be high by the extent of the contribution of absorbed ammonia to urea synthesis. 
On the high plane of nutrition, the rate of entry of urea was such that pregnant and non-pregnant sheep could synthesize, at a maximum, $64 \mathrm{~g} / \mathrm{d}$ of glucose from amino acids if all residues were used for glucose synthesis (Table 2).

It has recently been shown (Leng et al. I967) that non-pregnant sheep given $800 \mathrm{~g}$ lucerne chaff daily synthesize $45-62 \%$ of their glucose from propionate and $30-40 \%$ when pregnant (Steel \& Leng, 1968). The gluconeogenic amino acids on deamination enter the same pools of the carboxylic acid cycle intermediates as propionate and therefore only a proportion of the amino acid residues will be used for glucose synthesis (Leng, 1970).

The rate of synthesis of glucose is reduced when intake of food is limited or when feed is withheld (Bergman, 1963; Kronfeld \& Simesen, 1961; Ford, 1963; Steel \& Leng, I968; Judson \& Leng, I968) and on the $25 \circ \mathrm{g}$ ration the glucose entry rate was probably decreased in all the animals. For instance, Steel \& Leng (1968) showed that only $60 \mathrm{~g}$ of glucose were synthesized daily from all substrates in smaller sheep starved for $4 \mathrm{~d}$ at the same stage of pregnancy as the sheep in these studies.

The greater rate of entry of urea in the underfed pregnant sheep in these studies indicated that more of the available amino acids (of exogenous and endogenous origin) were degraded in the pregnant than in the non-pregnant ewes. The potential for glucose synthesis was correspondingly greater for the pregnant $\left(45^{-} 5^{2} \mathrm{~g} / \mathrm{d}\right)$ than for the non-pregnant $(35 \mathrm{~g} / \mathrm{d})$ sheep, but despite the greater potential for glucose synthesis, the glucose requirements of these sheep were not met fully since the animals were hypoglycaemic.

Even if the rate of propionate production had been reduced to $25 \%$ in the underfeeding period, presumably a considerable quantity of glucose may have been synthesized from this substrate. Also the ketonaemia (Table I) suggests an increased mobilization of fat (Leng \& West, I969), and glycerol (Bergman et al. 1968) may also have contributed significantly to the glucose synthesis. It seems unlikely that glycerol could make a large contribution to glucose synthesis because of the large amount of long-chain fatty acids that would have to be mobilized to make I mole of glycerol available (Leng, 1970).

It is now quite widely held that some of the urea returned to the digestive tract is utilized, if there is sufficient energy available, for microbial cell synthesis (see reviews by Phillipson, 1964; Waldo, I 968 ). If this is so, the present finding that pregnant sheep retain more urea than non-pregnant sheep and return more of it to the digestive tract would confer an additional ability to make use of low-protein, high-carbohydrate diets. These studies tend to support other studies from this laboratory which suggest that amino acids do not contribute the carbon needed for the major proportion of the glucose synthesized in sheep that are being fed. The low absolute capacity of previously well-nourished ewes to mobilize protein, at least during short periods of reduced food intake in late pregnancy, predisposes them to hypoglycaemia and pregnancy toxaemia.

We are indebted to the Australian Wool Research Committee, the Rural Credits Development Fund and the University of New England for financial support for this 
work. We thank Dr I. W. MacDonald for permission to use facilities at the Division of Animal Physiology, CSIRO, Prospect, NSW and Dr N. McC. Graham for giving us access to his experimental animals and to certain values cited in this paper. Mr R. Raabe provided competent technical assistance.

\section{REFERENCES}

Alexander, D. P., Nixon, D. A., Widdas, W. F. \& Wohlzogen, F. X. (1958). F. Physiol., Lond. 140, I. Armstrong, D. G. \& Beever, D. E. (1969). Proc. Nutr. Soc. 28, I21.

Assali, N. S., Dilts, P. V., Plentl, A. A., Kirschbaum, T. H. \& Gross, S. J. (1968). In Biology of Gestation Vol. I [N. S. Assali, editor]. London: Academic Press.

Barcroft, J. (I946). Researches on Pre-natal Life. Oxford: Blackwell.

Beaton, G. H. (1 957). Archs Biochem. Biophys. 67, I.

Bergman, E. N. (1963). Am. F. Physiol. 204, I47.

Bergman, E. N., Roe, W. E. \& Kon, K. (1966). Am. F. Physiol. 211, 793.

Bergman, E. N., Starr, D. J. \& Reulein, S. S. Jr (1968). Am. F. Physiol. 215, 874.

Botella-Llusia, J. (1936). Arch. Gynaek. r6x, 254.

Clark, R. (1965). Il S. Afr. vet. med. Ass. 36, 75 .

Cocimano, M. R. \& Leng, R. A. (1967). Br. F. Nutr. 2r, 353.

Dintzis, R. Z. \& Hastings, A. B. (I953). Proc. natn. Acad. Sci. U.S.A. 39, 57 I.

Forbes, J. M. (1968). F. agric. Sci., Camb. 72, I 19.

Ford, E. J. H. (1963). Biochem. F. 88, 427.

Graham, N. McC. (1968). Aust. F. agric. Res. 19, 555.

Graham, N. McC. \& Williams, A. J. (1962). Aust. J. agric. Res. 13, 894.

Hecker, J. F. ( 1967 ). Studies on the metabolism of nitrogenous compounds in the large intestine of herbivores. PhD Thesis, University of Cambridge.

Houpt, T. R. (1959). Am. F. Physiol. 197, II5.

Huggett, A. St G. \& Nixon, D. A. (1957). Biochem. F. 66, 12P.

Judson, G. J. \& Leng, R. A. (1968). Proc. Aust. Soc. Anim. Prod. 7, 354.

Kornberg, H. L., Davies, R. E. \& Wood, D. R. (1954). Biochem. F. 56, 363.

Krebs, H. A. (1964). In Mammalian Protein Metabolism Vol. I., Ch. 5, p. I63 [H. N. Munro and J. B. Allison, editors]. London: Academic Press.

Kronfeld, D. S. (1957). Aust. F. exp. Biol. med. Sci. 35, 257.

Kronfeld, D. S. \& Simesen, M. G. (1961). Am. F. Physiol. 201, 639.

Leng, R. A. (1970). Adv. vet. Sci. 14, 209.

Leng, R. A., Steel, J. W. \& Luick, J. R. (1967). Biochem. f. 103, 785.

Leng, R. A. \& West, C. F. (1969). Res. vet. Sci. 10, 57.

Levenson, S. M., Crowley, L. V., Horowitz, R. E. \& Malm, O. J. (1959). F. biol. Chem. 234, 206 r.

Marsh, W. H., Fingerhut, B. \& Kirsch, E. (1957). Am. F. clin. Path. 28, 68 1.

Nolan, J. V. \& Leng, R. A. (1968). Proc. Aust. Soc. Anim. Prod. 7, 378.

Packett, L. V. \&c Groves, T. D. D. (1965). F. Anim. Sci. 24, 34 I.

Patterson, M. S. \& Greene, R. C. (1965). Analyt. Chem. 37, 854.

Phillipson, A. T. (1964). In Mammalian Protein Metabolism Vol, I, p. 7I [H. N. Munro and J. B. Allison, editors]. London: Academic Press.

Raabe, R. (1968). Lab. Pract. 17, 217.

Rahman, S. A. \& Decker, P. (1966). Nature, Lond. 209, 6 I8.

Reid, R. L. (1960). Aust. F. agric. Res. Ir, 364.

Robinson, J. J. \& Forbes, T. J. (1967). Br. F. Nutr. 21, 879.

Schmidt-Nielsen, B., Schmidt-Nielsen, K., Houpt, T. R. \& Jarnum, K. (1957). Am. F. Physiol. r88, 477.

Steel, J. W. \& Leng, R. A. (1968). Proc. Aust. Soc. Anim. Prod. 7, 342.

Tanayama, S. \& Ui, M. (1963). Chem. pharmaceut. Bull., Tokyo II, 835 .

von Engelhardt, W. \& Nickel, W. (r965). Pfiugers Arch. ges. Physiol. 286, 57.

Waldo, D. R. (1 968). F. Dairy Sci. 51, 265.

Wilson, B. W. (1966). Clin. Chem. 12, $23^{\circ}$. 